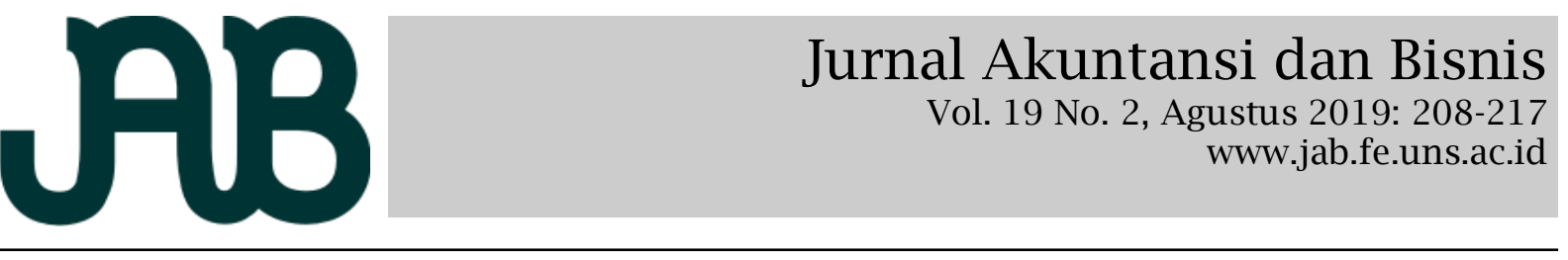

\title{
JAVANESE LOCAL WISDOM IN FAMILY BUSINESSES
}

\author{
Titik Setyaningsih ${ }^{1}$ (titiksetyauns@gmail.com) \\ Andi Asrihapsari ${ }^{2}$ \\ Pram Suryanadi ${ }^{3}$
}
${ }^{1,2}$ Accounting Study Program, Faculty of Economics and Business, Universitas Sebelas Maret, Indonesia
${ }^{3}$ Management Study Program, Faculty of Economics and Business, Universitas Sebelas Maret, Indonesia

\begin{abstract}
A B S T R A C T
This study aims to analyze the implementation of Javanese local wisdom in accounting equations and accounting transactions, especially in family businesses. Javanese local wisdom is a perspective for developing new knowledge. This study uses a qualitative method. It is descriptive practice-oriented research. The data was gathered through observation and interviews. The informants consisted of native Javanese business managers (of proprietorships, partnerships and limited liability companies). The findings show that the values of Javanese local wisdom can be implemented in a company even though they are implemented only in a few transactions. The meaning of "katentreman ati" (real happiness) and "tulung tinulung" (helping each other) can be achieved by this study. There are two interesting problems to think about regarding the implementation of the value of local wisdom: the exploration of local genius and an alternative mindset of local wisdom in accounting. The values of local wisdom can only be well implemented with a commitment to share these values with future generations.

Keywords: Javanese local wisdom, descriptive practice-oriented research, commitment.

Penelitian ini bertujuan untuk menganalisis implementasi nilai kearifan lokal Jawa dalam persamaan akuntansi dan transaksi akuntansi terutama dalam bisnis keluarga. Nilai kearifan lokal Jawa merupakan suatu perspektif untuk mengembangkan pengalaman baru. Penelitian ini menggunakan metode kualitiatif. Penelitian menggunakan riset berorientasi pada deskriptif praktik. Data dikumpulkan melalui observasi dan wawancara. Informan terdiri dari pelaku usaha yang merupakan jawa asli selaku pemimpin bisnis (perusahaan perseorangan, persekutuan dan perseroan terbatas). Hasil penelitian menunjukkan kearifan lokal Jawa dapat diimplementasikan dalam suatu perusahaan meskipun hanya beberapa transaksi. Arti "katentreman ati" (kedamaian hati) dan "tulung tinulung" (saling membantu satu dengan yang lain) dapat dicapai. Terdapat dua permasalahan yang menarik untuk dipikirkan terkait implementasi nilai kearifan lokal yaitu mengeksplorasi kecerdasan lokal dan pandangan alternatif terhadap kearifan lokal. Nilai kearifan lokal dapat diimplementasikan dengan baik dengan komitmen untuk berbagi nilai dengan generasi berikutnya.
\end{abstract}

Kata Kunci : kearifan lokal jawa, riset berorientasi deskriptif praktik, komitmen

\section{INTRODUCTION}

Accounting is the universal language of business. The better somebody understands accounting, the better he will manage his business (Horngren and Harrison, 2007). In accounting, as in other areas of business, we frequently encounter ethical dilemmas. The decision-making process is more difficult because there is no compre- hensive ethical system to provide guidelines.

The application of local wisdom has a positive impact on business (Hakimah, 2016; Fauji, Wahyuningsih \& Wardani, 2016; Adhitya, 2018). According to Sartini (2004), local wisdom is local ideas that are wise, thoughtful, have a good value, are embedded, and are followed by members 
of a community. Local wisdom is established as local cultural excellence as well as unique potential. Local wisdom is a product of past cultures that should be used as a lifeline. Even though local wisdom is applied locally, its values are highly universal.

When a company inflicts harm on a community in its activities for generating profit, the company will face the community, both as the general public and as individuals involved in the company's activities. A sustainable business is a business that pays attention to the threats its business poses to the environment and is responsible for these threats, as well as its profit-generating activities (Savitz and Weber, 2006).

Inappropriate accounting techniques have been reported by Toshiba. Investigators found evidence of booking future profits early, pushing back losses, pushing back charges and other similar techniques that resulted in overstated profits. The investigative panel concluded that Toshiba's corporate culture, which demanded obedience to superiors, was an important factor enabling the emergence of fraudulent accounting practices (Carpenter, 2013). Horngren and Harrison (2007) stated that ethical practice is the implementation of a good business. Truth is always better than a lie and this rule applies in accounting, business, and overall life activities.

The most highlighted issue in Indonesia is the case of Century Bank bailout which was processed by KPK (Komisi Pemberantasan Korupsi-Committee for Corruption Eradication). Jusuf Kalla judged that Century Bank bailout was a wrong policy and violated the law. Kalla also stated that Century Bank was 'robbed' by its owner, thus its owner was the person who had to take the responsibility, not the government (regional.kompas.com).

The above cases show the necessity of understanding new knowledge in an organization. In organizations where fraudulent acts are highly tolerated, unlearning old knowledge will require leadership figures to administer strong shocks to tip the balance of their subordinates' costbenefit considerations to drive them to un- learn the obsolete knowledge and learn the new. We not only need to learn but also to unlearn. Research about individual and organizational unlearning has been conducted by several researchers (Bierly, Hessler \& Christensen 2000; Duffy, 2003; Becker, 2005; Rowley, 2006; Hays, 2007; Spiller, Pio, Erakovic \& Henare, 2011; Wong, Cheung, Yiu, \& Hardie, 2012; Zhao, Lu \& Wang, 2013).

In Indonesia research about local wisdom in accounting has been conducted by several researchers (Hanif, Rahman \& Zaki, 2013; Wibowo, 2014; Efferin, 2015; Adhiputra, 2016; Budiasni and Dharma, 2016; Supatmi, 2019). This research aims to find the meaning of local wisdom, and especially the implementation of Javanese local wisdom in business transactions and its record in a family business.

Based on the above background, the formulation of the problem of this research is: how are the values of local wisdom applied in business? The motivation of this research is the researcher's wish to explore the values of local wisdom and its implementation in business activities. By understanding the values embedded in the local wisdom, businessmen will be able to conduct their business activities and implement the accounting equation not only based on an economic standpoint, or a perspective of social responsibility, and religiosity, but also to develop local culture. The difference between this research and previous research is that this research explains the implications of the outcome if a business transaction is conducted based on local wisdom or if it ignores the values of local wisdom. The following section discusses the literature review and is followed by the methodology, results, conclusions, and limitations of the study.

\section{LITERATURE REVIEW}

\section{Accounting Theories}

Accounting theories have experienced a shift from a normative approach to a more positive approach that resembles empirically oriented research and justifies various accounting techniques or methods (Watts and Zimmerman, 1986). Various approaches are used to formulate an accounting the- 
ory. Based on the advantages and weaknesses of each approach, we can expect that these conditions will bring about a useful debate and an integrated accounting theory. This view may be followed by people who believe that an improvement in accounting will be attained through the accumulation of new ideas or evolution.

\section{Accounting: multi-paradigmatic knowledge}

If accounting stands on a critical stage, then it becomes possible to identify various competing paradigms. In other words, accounting is multi-paradigmatic knowledge, in which each paradigm is competing to rule the accounting discipline.

Each paradigm will posit its examples, theories, and methods. Specifically, each competing accounting paradigm tends to specify an empirical domain where an accounting theory should stand. The positive theory is criticized by researchers. Their criticism can be classified into three categories:

1. Criticism of philosophy; positivist researchers. This philosophy is criticized because a researcher cannot be outside his research area.

2. Criticism of methodology; positivists argue that profit maximization can be achieved through market equilibrium price. Again, this condition is not possible because research on market equilibrium price has a very small contribution to accounting research.

3. Criticism of economic approach, namely that it is impossible to count individual satisfaction (Januarti, 2004).

\section{Ethics and Dimensions of Business}

The point of ethics is to study the behavior of an individual, group, or organization that is constituted as good or not. According to Agoes and Ardana (2009), the point of human ethics is a balance in :

1. Personal interest, community interest, and God interest.

2. Material capital, social capital, and spiritual capital.

3. Physical happiness (secular), social welfare, and psychological happiness (heavenly); as well as a balance in indi- vidual rights and the responsibility of individuals to their community and God.

The assessment of whether a business is ethical or not is based on the dimensions of economics, ethics, law, sociality, and spirituality. The economic dimension views a business as a series of productive activities to generate profit. In generating profit, business activities must be accountable and not harmful to the community or damaging to the environment (ethical dimension). The legal dimension requires a company to obey the law in a country. The social dimension requires a company to produce goods and services needed by the public. Business activities also have a spiritual dimension which means that business activities must be based on faith and devotion to God, aim to increase community welfare, and support environmental sustainability in conducting the business activities (the teonom theory by Peschke S.V.D as cited in Agoes and Ardana (2009)).

\section{Organizational Wisdom}

The theory of meta-synthetic wisdom, which attempts to explore wisdom as understood in Western and Eastern and meta-synthesis, is guided by scientific philosophy, integrated natural science, social science, engineering science, art, and culture, or in short integrates and synthesizes all useful theories together to obtain wisdom. Based on the dialectical materialism, this theory tries to use the human-machine combination emphasizing the human and to collect all available information, experiences, knowledge, and wisdom from both historical and modern times, especially web wisdom. This theory combines qualitative wisdom (natural wisdom) and quantitative wisdom (magnitude wisdom), science and art, logical thinking and imagery thinking (Qian, 2002).

The term unlearning has been used in several different contexts. Some have referred to this concept about individuals undergoing a process of relinquishing old ways and embracing new behaviors, ideas or actions (Duffy, 2003; Wong et al., 2012). Duffy (2003) states that left unexamined and unchallenged, mental models influence 
people to see what they have always seen, do what they have always done, be what they have always been, and therefore produce the same results.

Other researchers have focused more upon organizations as a system, relinquishing previous methods and approaches to accommodate changing environments and circumstances internal to the organization (Bierly et al., 2000; Rowley, 2006; Hays, 2007; Spiller et al., 2011; Zhao et al., 2013). Becker (2005) created a model of unlearning that integrates individual and organizational perspectives. According to Rowley (2006), wisdom is 'the capacity to put into action the most appropriate behavior, taking into account what is known (knowledge) and what does the best (ethical and social considerations)', attaining organizational wisdom is a process of a higher level than merely achieving organizational knowledge.

\section{Good Governance}

According to the Indonesian Code about good corporate governance published by the National Committee on Governance 2006, good corporate governance covers five principles: transparency, accountability, responsibility, independence, and fairness. All of these principles must work together to achieve good corporate governance.

Transparency means managers have a responsibility to implement a principle of transparency in the decision-making process and in conveying information to the stakeholders. Accountability is a principle in which managers should manage the accounting system effectively to make an appropriate financial statement. Responsibility is a principle that requires managers to be responsible for all aspects of the business on behalf of the stakeholders. Independency is a condition in which managers are professional, independent, free from conflict of interest, and free from any pressure in making decisions. Fairness means that managers treat all the stakeholders fairly and equally, including both primary stakeholders (suppliers, customers, employees, and investors) and secondary stakeholders (government, community, and other stakeholders).

\section{Local Wisdom and Human Nature}

Local wisdom can be interpreted as local ideas that are wise and embedded in society (Kartawinata, 2011). The purpose of local wisdom is to find physical and spiritual meaning. However, physiological orientation, which underlies the 'external' culture, has its roots in capitalism, individualism, and intellectualism (Suratno and Astiyanto, 2009).

The teonom theory by Peschke S.V.D as cited in Agoes and Ardana (2009) states that human moral character is determined by its harmony with God's will. Human behavior is considered good if it is consistent with God's will or God's law.

Covey (2005) points out that building human character needs an integral and balanced development of competence in four capacities, namely the physical (physical quotient or PQ); intellectual (intellectual quotient or IQ); emotional (emotional quotient or EQ); and spiritual (spiritual quotient or SQ). However, according to Nafis (2006), it is human nature to maintain a balance between psychological ethics, social ethics, and theological ethics.

Suratno and Astiyanto (2009) underline the need to review whether 'external' culture is highly suitable for a community's life and needs to fully understand one's nature and identity as an individual creature, social creature, and creature of divine creation. Therefore, every human action must be oriented to create a result that can provide physical and psychological pleasure. Local wisdom is a noble culture that supports the ethics theory and will create local genius.

The existence of local genius in a community will enhance a nation's civilization. This local genius will process outside culture and adjust it to suit the needs of a community. Local genius grows from a tradition that is developed from a local community. The elements of culture that are not in line with cultural law will be abandoned. The Javanese are well known for their tolerance and justification of every event (Kompas, 22 May 2014).

The findings of Hanif et al. (2013) 
show that the Padang $X$ Restaurant group has a distinct uniqueness in its management. A profit-sharing system is well implemented by emphasizing the principles of good governance. Piti (money, Padang dialect) worth even one rupiah is viewed as common property, thus binding the behavior to work together in achieving organizational goals. Wibowo (2014) analyzed local wisdom in lumbung desa or the village barn (a place where villagers store their reserves of rice) as a social safety net for villagers to improve the food security system in a rural community. Lumbung de$s a$ is based on the value of gotong-royong (togetherness) and prioritizes common welfare through the improvement of good governance.

Local wisdom has a contribution to make in transactions. The accountability of a company's activities about community needs should respect the values of local wisdom, to create harmony between the business, community, environment, and God (Efferin, 2015; Adhiputra, 2016; Budiasni and Dharma, 2016; Supatmi, 2019). This research is not only concerned with individuals but also the organizational context, and the implications of economic transactions using values of Javanese local wisdom. This research builds a model that applies the values of local wisdom that are different from conventional accounting. Previous studies have only relied on a single local wisdom value, for example (Wibowo, 2014) only included the value of cooperation.

\section{RESEARCH METHODOLOGY}

A qualitative method was used in this research to gain a better understanding of the phenomena explored. The advantage of a qualitative method is its ability to analyze the environment naturally (Sekaran and Bougie, 2010).

Cresswell (2010) explained that there are five types of qualitative research: phenomenology study, ethnographic study, grounded theory of qualitative research, biographic study, and case study. This research is a single case study. The paradigm used in this study is an interpretative paradigm, which focuses on the mindset, ethics, and human behaviors that are considered to be actions involving intention, awareness, and specific reasons, and depend on the people who give meaning and interpretation to the social phenomena (Bungin, 2007). The research design helps to find the meaning of values of local wisdom and discover how the values are implemented in business transactions. The procedures followed are data collection (observation and FGD) and data analysis (practiceoriented research).

\section{Data Collection}

The data in this study was collected through an in-depth observation of organizational activities. The stages of data collection are outlined below:

1. Focus Group Discussion (FGD)

The FGD was joined by informants related to local wisdom. By conducting an FGD, the researcher hoped to identify various contextual problems related to local wisdom. The FGD was held in UNS Inn on May 6, 2017.

2. Observation

The observation was carried out to gather the primary and secondary data by observing directly the activities of company management related to the company's accounting transactions. The observation of forms of Javanese local wisdom was conducted in the companies CV Romiz Aisy, CV Fascho Grafika and PT Intan Pariwara. All of the informants (CEOs) were native Javanese people from the Solo region (Surakarta and Sukoharjo) which is well known as a center of Javanese culture. The observations were conducted in March, April, and May 2017.

\section{Data Analysis}

This study is practice-oriented research. This type of study does not need to propose or to test a hypothesis (Dul and Hak, 2008).

Practice-oriented research was preferred because it aims to provide experiences that contribute to finding a solution or clarifying the implementation of accounting transactions through the understanding of values of local wisdom in fami- 
ly businesses. The researcher wished to explore the understanding and constraints in the implementation of local wisdom values itself, so the informants (CEO's with experience in three different forms of companies) were considered representative to answer the research questions.

Data triangulation was conducted by comparing interview results and observation data. Triangulation can also be conducted by comparing the findings with the theory.

\section{RESULTS}

\section{Accounting Equation Based on Local Wis- dom}

The basic accounting instrument is the accounting equation. The equation measures a company's resources and claims over the resources. Assets are economic resources that are expected to give advantages to the company in the future. The claim on these assets comes from two sources, liabilities and equity (capital). Liabilities are debts that must be paid to outside parties or creditors. The owner's claim on a company's assets is referred to as the owner's equity or capital. The claim from the internal party exists since the owner invests his assets in the company (Horngren and Harrison, 2007).

The ancestral teachings contained in local wisdom are intended to harmonize the mindset with the noble values of the nation, and especially the community. Wealth (sugih tanpa bandha, rich without money) to the naked eye is unlikely to mean 'rich but not possessing property/ wealth'. Javanese people have a view of life known as samadya (fair and sufficient), which shows that there is no orientation to become excessively rich (ora ngoyak $\mathrm{ka}$ donyan). This noble manner is related to a person's social role. A person who has a noble character is a person who is helpful to other people's lives (Suratno and Astiyanto, 2009).

A family business is managed by maintaining a principle of cooperation among the family members. Assets in the company may be cash, receivables, equipment, office supplies, inventory, vehicles, land, buildings, and various other forms, but they are managed to gain benefits for family members in particular and the community in general. Faith in the afterlife carries the belief that wealth will not be taken to death, thus, it should be reinvested in good deeds.

For Javanese people, wealth is not everything. Happiness is not only determined by how much wealth somebody has. Tuna satak bathi sanak (profit) is in line with sugih tanpa bandha in the trade business, where profit is not always bathi dhuwit or bathi satak (financial profit). For a merchant, or in the Javanese language known as bakul, having relatives or associates in running a business is also considered to be a profit. A merchant tries to make the consumers happy to create a harmonious and sustainable relationship. A merchant prefers to have a small profit but many sanak or relatives (Suratno and Astiyanto, 2009).

The principle tuna satak bathi sanak (gain less profit to get more relatives) can be used to build a network of customers who are loyal to the company. An increasing number of customers will add to the company's value and trust in a product that is marketed by the company. This attitude will make the incoming cash from the customers more reliable, thus, the company's business operation will be sustained.

In addition to needing capital, a business sometimes also needs debt. A conventional debt to a bank will result in a consequence of interest expense. A debt in Javanese local wisdom can be taken with tulung -tinulung (helping each other) which means mutual help. This means that in life, people have to help each other whether in conditions of suffering or happiness. The purpose is to alleviate a common burden.

Credit that is based on the intention of tulung-tinulung does not require a certain interest rate like in a bank. This kind of credit appreciates the intention to return the money according to the specified time and amount, based on the debtor's ability. For example, when we borrow from our relatives, this kind of debt can be returned only as the principal amount without interest. Even if an amount that is more than the initial loan is returned, the excess of 
the return is adjusted to the debtor's ability, based on sincerity, and is not burdensome for the relative.

According to a wayang purwa story, Pandhu Sraya (help), a wise person will always teach his knowledge to others, so that others will be able to overcome the difficulties they face in life (Probohardjono, 2002). People must be sincere when helping others. When there is somebody who is not able to return a favor that was given, it is better if we consider the favor like a plant that we will harvest fruit from in the future.

Table 1 shows the difference in the accounting equation in a business that is based on local wisdom, namely by reaching katentreman ati (peace of heart). Javanese people have faith in sapa nandur bakal ngundhuh (whomever plants will reap the harvest). This value will lead Javanese people to change their interest in assets (bandha) by pursuing real happiness or peace of heart (katentreman ati). They believe that "God is not sleeping and is always watching their activities". This value of local wisdom means to get rich from the heart (sugih aja mung sugihing bandha, ning sugiha kaselehing ati).

The accounting equation based on local wisdom supports the principles of good governance which link all occurring conditions with the existence of God's power. Local genius and local wisdom support the concept of a real personality (Covey,

Figure 1.

Real Personality Based on Local Wisdom

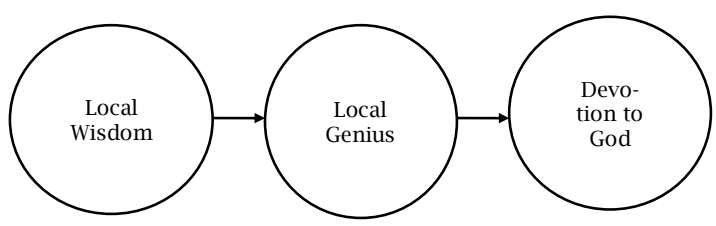

2005; Nafis, 2006). One thing that differentiates this is that real personality based on local wisdom will result in local genius as a form of devotion to God. Local genius brings together all the elements of $\mathrm{PQ}, \mathrm{IQ}$, EQ, and SQ (Figure 1).

\section{The Implementation of Local wisdom}

The observation of forms of Javanese local wisdom was conducted in the companies CV Romiz Aisy, CV Fascho Grafika and PT Intan Pariwara. All of the informants were native Javanese people from the Solo region (Surakarta and Sukoharjo) which is well known as a center of Javanese culture.

The owners or Chief Executive Officers of these companies still combine conventional accounting transaction practices and local wisdom that they can implement. Some illustrations of the transactions are as follows:

\section{The decision to "do orders not only with machines"}

The company in question is engaged in publishing, printing, and trading. Using a machine will enable the company to be more cost-efficient in producing completed books. Even though the owner has received an offer with an affordable price and has sufficient cash to purchase the machine, he has decided not to purchase it because:

- Even if I have a machine, we still need to share our profit with society, sometimes we have an overload of orders, that's why we need them to work. I hire 20 people to bind the books. (S)

- You know family businesses can succeed too, especially our company. PT Intan Pariwara is a big company, we always open recruitment to fulfill the sales and administration function. We,

Table 1.

The Difference in Accounting Equations

\begin{tabular}{|c|c|}
\hline Conventional & Local Wisdom \\
\hline$A$ ccotc - Equitu & $\begin{aligned} \text { Assets }(\text { bandha })= & \text { Liabilities (tulung-tinulung) }+ \text { Equity } \\
& \text { (tuna satak bathi sanak) }\end{aligned}$ \\
\hline Assets $=$ Liabilities + Equity & \\
\hline Assets - Liabilities = Equity & $\begin{aligned} \text { Wealth }(\text { sugih tanpa bandha })= & \text { real happiness } / \text { peace of } \\
& \text { heart (katentreman ati) }\end{aligned}$ \\
\hline
\end{tabular}

Source: Processed secondary data 
of course, always get an overload of orders because we have 17 stores around Indonesia. Of course, orders are done by machine, but the company hires 100 people to do the packaging. (T)

The informant emphasized that in the short term, the result may be less effective and efficient, but long-term accountability will be achieved because of a good relationship with the community, which is a more valuable investment.

\section{Lending transaction with relatives (sanak sadhulur)}

The owner of CV Romiz Aisy keeps trying to manage and develop his tulung-tinulung network and tries to cut down bank loans by increasing customer loyalty.

Peace of heart will be attained if a person can adjust his ability by managing his finance, and his relatives' and friends' finances, without being pursued by interest payment. In the future, nrima ing pandum will translate to an independent business without debts. Thus, it will create the expectation of local wisdom that is true happiness (katentreman ati).

\section{Sharing orders}

The Javanese local wisdom value tulungtinulung can make sanak sadhulur (friends and relatives). PT Intan Pariwara and PT Tiga Serangkai has been well developed by sharing orders.

\section{Sharing values with future generations}

The informants try to share their knowledge, values, vision, mission, and culture with the next generation. Consequently, there is a process of learning and changing. All the principles of good governance have been implemented at PT Intan Pariwara, while the other companies have only successfully implemented two principles: responsibility and fairness. PT Intan Pariwara hires a professional to manage the business. In small enterprises (CV Romiz Aisy and CV Fascho Grafika), it may be impractical to prohibit family members from supervising one another. PT Intan Pariwara assigns an experienced nonfamily employee to provide an objective performance evaluation.

\section{CONCLUSION}

Based on the results, values of local wisdom can be implemented in a company's accounting transactions (as an alternative choice for the company to maintain a harmonious social life). This study shows that the value which differentiates the accounting equation based on local wisdom and the conventional accounting equation is the existence of katentreman ati (peace of heart) which is not seen in the conventional accounting equation.

Some principles of good governance can be implemented in business transactions which include local wisdom values. Only PT Intan Pariwara has implemented all the principles of good governance well, while others have only managed to implement two principles: responsibility and fairness (equality).

The limitation of this study is that the results of the study cannot be applied generally to conventional businesses. The researcher recommends further studies to explore the dimension of katentreman ati to explain local genius, and the use of multiple data to compare family businesses and nonfamily businesses.

\section{REFERENCES}

Adhiputra, M.W. (2016). Kewirausahaan mandiri perempuan berbasis kearifan lokal dan filosofi Hindu di Bali. Jurnal Riset Ekonomi dan Manajemen, 16 (2), 237-246.

Adhitya, F. (2018). Pendekatan dengan konsep SIMARK untuk melestarikan local wisdom di dalam masyarakat. Jurnal STIE Semarang, 10(1), 38-52.

Agoes, S., \& Ardana, I.C. (2009). Etika bisnis dan profesi, tantangan membangun manusia seutuhnya. Jakarta: Salemba Empat.

Bierly, P.E., Hessler, E.H., \& Christensen, E.W. (2000). Organizational learning, knowledge and wisdom. Journal of Organizational Change Management, 13(6), 595-618.

Becker, K. (2005). Individual and organisational unlearning: Directions for future research. International Journal of Organisational Behaviour, 9(7), 659670.

Budiasni, N.W.N., \& Darma, G.S. (2016). Penerapan corporate social responsibility 
pada lembaga keuangan berbasis kearifan lokal. Jurnal Manajemen dan Bisnis, 13(2), 1-19.

Bungin, B. (2007). Analisis data kualitatif: pemahaman filosofis dan metodologis ke arah penguasaan model aplikasi. Jakarta: PT Rajagrafindo Persada.

Carpenter, J.W. (2013). Toshiba's accounting scandal: How it happened (OTCBB:TOSBF). Diakses dari http:// www.investopedia.com.

Cresswell, J.W. (2010). Research design pendekatan kualitatif, kuantitatif, dan mixed (Edisi ketiga). Yogyakarta: Pustaka Pelajar.

Covey, S.R. (2005). The $8^{\text {th }}$ habit: melampaui efektivitas, menggapai keagungan. Jakarta: Gramedia Pustaka Utama.

Duffy, F.M. (2003). I think, therefore I am resistant to change. Journal of Staff Development, 24(1), 30-36.

Dul, J., \& Hak, T. (2008). Case study methodology in business research. Oxford, UK: Elsevier Ltd.

Efferin, S. (2015). Akuntansi, spiritualitas, dan kearifan lokal: Beberapa agenda penelitian kritis. Jurnal Akuntansi Multiparadigma (JAMAL), 6(3), 341511.

Fauji, D.A.S., Wahyuningsih, T., \& Wardani, K. (2016, 5 Oktober). Memaknai etika bisnis berbasis kearifan lokal pada sentra indutri tahu kota Kediri. Paper dipresentasikan pada acara Seminar Nasional Manajemen (SENIMA), Surabaya.

Hanif, U.L., Rahman, A.F., \& Zaki, B. (2013, 25-28 September). Refleksi nilai-nilai Pancasila dalam akuntansi bagi hasil. Paper dipresentasikan pada acara Simposium Nasional Akuntansi XVI, Manado.

Hakimah, E.N. (2016, 5 Oktober). Optimalisasi konsep pemasaran CRM (Customer Relationship Marketing) menggunakan pendekatan kearifan lokal pada ritel konvensional di Kecamatan Kandat dan Ngadiluwih Kabupaten Kediri. Paper dipresentasikan pada acara Seminar Nasional Manajemen (SENIMA), Surabaya.

Hays, J.M. (2007). Dynamics of organizational wisdom. Journal of Global Strategic Management, 1(1), 17-35.

Horngren, C.T., \& Harrison Jr., W.T. (2007). Akuntansi jilid 1 (Edisi 7). Jakarta: Penerbit Erlangga.

Januarti, I. (2004). Pendekatan dan kritik akuntansi positif. Jurnal Akuntansi dan Auditing Universitas Diponegoro, 1 (1).
Kartawinata, A.M. (Editor). (2011). Buku kearifan lokal di tengah modernisasi. Jakarta: Puslitbangbud Badan Pengembangan Sumber Daya Kebudayaan dan Pariwisata Kementerian Kebudayaan dan Pariwisata Republik Indonesia.

Kompas. (2014). Kecerdasan lokal majukan peradaban. Harian Kompas, 22 Mei 2014. Cetak.

Kompas.com. (2012). Kalla: Bank Century dirampok. Diakses dari https:// tekno.kompas.com.

Nafis, M.W. (2006). Sembilan jalan untuk cerdas emosi dan cerdas spiritual. Jakarta: Hikmah.

National Committee on Governance. (2006). Indonesia's code of good corporate governance. Diakses dari www.ecgi.org.

Probohardjono, S. (2002). Pakem pedalangan cerita wayang purwa jilid 2. Surakarta: CV Ratna Pusaka.

Qian, X.M. (2002). Theory of meta-synthetic wisdom. Diakses dari http:// www.xinhuawz.com.

Rowley, J. (2006). What do we need to know about wisdom? Management Decision, 44(9), 1246-1257.

Sartini. (2004). Menggali kearifan lokal nusantara sebuah kajian filsafati. Jurnal Filsafat, 37(2), 111-120.

Savitz, A.W., \& Weber, K. (2006). The triple bottom line: how today's best-run companies are achieving economic, social, and environmental success-and how you can too. San Francisco, CA: Jossey-Bass.

Sekaran, U., \& Bougie, R. (2010). Research method for business, a skill building approach (5th ed.). New York: John Willey \& Sons, Inc.

Spiller, C., Pio, E., Erakovic, L., \& Henare, M. (2011). Wise up: Creating organizational wisdom through an ethic of Kaitiakitanga. Journal of Business Ethics, 104(2), 223-235.

Supatmi. (2019). Local wisdom: Deskripsi, tantangan, dan peluangnya dalam penelitian interpretif. Perspektif Akuntansi, 2(2), 121-141.

Suratno, P., \& Astiyanto, H. (2009). Gusti ora sare: 90 mutiara nilai kearifan budaya Jawa. Yogyakarta: Adiwacana.

Watts, R., \& Zimmerman, J.L. (1986). Positive accounting theory. USA: Prentice Hall.

Wibowo, A.C. (2014). Akuntabilitas lumbung desa: suatu penelaahan tata kelola yang bersumber dari kearifan lo- 
JURNAL AKUNTANSI DAN BISNIS Vol. 19, No. 2, Agustus 2019: 208-217

kal masyarakat Desa Dempel, Kecamatan Geneng, Kabupaten Ngawi (Tesis). Universitas Sebelas Maret, Magister Akuntansi Fakultas Ekonomi dan Bisnis, Surakarta.

Wong, P.S.P., Cheung, S.O., Yiu, R.L.Y., \& Hardie, M.P. (2012). The unlearning dimension of organizational learning in construction projects. Internation- al Journal of Project Management, 30 (1), 94-104.

Zhao, Y., Lu, Y., \& Wang, X. (2013). Organizational unlearning and organizational relearning: a dynamic process of knowledge management. Journal of Knowledge Management, 17(6), 902912. 